В журнале Вестник РГМУ (июль-август 2018/04, с. 37-44) были допущены ошибки в статье:

\title{
ОПЫТ ИСПОЛЬЗОВАНИЯ АНАЛИТИЧЕСКОГО СТЕНДА ДЛЯ ПРОВЕДЕНИЯ АЭРОЗОЛЬНЫХ ИСПЫТАНИЙ В КОНТРОЛИРУЕМЫХ УСЛОВИЯХ
}

Д. А. Клейменов, Б. И. Вердиев, А. А. Ененко, В. А. Гущин, А. П. Ткачук

$\bigotimes$ Для корреспонденции: Денис Александрович Клейменов

ул. Гамалеи, д. 18, г. Москва, 123098; 10000let@rambler.ru, denis.a.kleymenov@gamaleya.org

Статья получена: 06.08.2018 Статья принята к печати: 31.08.2018

DOI: $10.24075 /$ vrgmu.2018.053

Редакция просит учесть следующие изменения:

\begin{tabular}{|c|c|c|}
\hline & Напечатано: & Должно быть: \\
\hline $\begin{array}{l}\text { с. } 37, \text { пункт } \\
\text { «Финансирование» }\end{array}$ & $\begin{array}{l}\text { Статья подготовлена при поддержке Министерства } \\
\text { здравоохранения Российской Федерации в рамках программы } \\
\text { «Национальная система химической и биологической } \\
\text { безопасности 2015-2020» и Министерства образования } \\
\text { и науки РФ в рамках проекта RFMEFI60117X0018. }\end{array}$ & $\begin{array}{l}\text { Статья подготовлена при поддержке } \\
\text { Министерства образования и науки РФ } \\
\text { в рамках проекта RFMEFI60117X0018. }\end{array}$ \\
\hline $\begin{array}{l}\text { с. } 37, \text { пункт } \\
\text { «Funding» }\end{array}$ & $\begin{array}{l}\text { This work was supported by the Ministry of Health of the Russian } \\
\text { Federation as part of the project The National System for Chemical } \\
\text { and Biological Security of the Russian Federation (2015-2020) and } \\
\text { by the Ministry of Education and Science as part of the project } \\
\text { RFMEFI60117X0018. }\end{array}$ & $\begin{array}{l}\text { This work was supported by the } \\
\text { Ministry of Education and Science } \\
\text { within the framework of the project } \\
\text { RFMEFI60117X0018. }\end{array}$ \\
\hline
\end{tabular}

